\title{
PENINGKATAN PEMAHAMAN PENGUSAHA BEBEK PETELUR MENGGUNAKAN SISTEM DRY HOME DAN MESIN PENGHALUS KEPALA UDANG PADA DESA CAMBAJAWA KABUPATEN MAROS
}

\author{
Irvawansyah $^{1^{*}}$, Alang Sunding ${ }^{2}$, Nurul Afifah ${ }^{3}$ \\ ${ }^{1}$ Program Studi Teknik Listrik, Politeknik Bosowa, Makassar, Indonesia \\ ${ }^{2}$ Program Studi Perawatan dan Perbaikan Mesin, Politeknik Bosowa, Makassar, Indonesia \\ ${ }^{3}$ Program Studi Perpajakan, Politeknik Bosowa, Makassar, Indonesia \\ * Penulis Korespodensi : irfun.elektro06@gmail.com
}

\begin{abstract}
Abstrak
Pertumbuhan penduduk usia produktif di Indonesia yang tidak diimbangi dengan ketersediaan lapangan kerja yang cukup, menyebabkan bertambahnya angka pengangguran. Pemerintah menggalakkan program wirausaha sebagai solusi dari peningkatan pengangguran. Salah satu wirausaha yang mempunyai prospek cukup baik adalah peternakan bebek petelur. Sebagai bahan pokok, permintaan telur bebek di pasaran relatif stabil. Program kemitraan masyarakat ini bertujuan untuk mengefisienkan waktu pembuatan tepung kepala udang sebagai komponen pakan yang paling penting dalam produksi telur bebek. Proses pembuatan tepung kepala udang yang dilakukan warga Maros selama ini terdiri dari 4 tahap yaitu: 1) Perebusan kepala udang, 2) Penjemuran kepala udang, 3) Penggilasan dan 4) penghalusan. Program kemitraan masyarakat ini menggunakan metode research and development. Hasil yang diperoleh dari pelaksanaan program ini yaitu : 1) efisiensi waktu mulai dari pengeringan kepala udang sampai pembuatan tepung kepala udang dari 2 hari menjadi 10 jam, 2) mitra dapat mengoperasikan mesin tepung dan memanfaatkan teknologi, 3) kapasitas produksi tepung udang meningkat karena waktu produksi tepung semakin pendek, 4) laba usaha meningkat sebesar Rp 14.230 atau 47,43\% dan aliran kas bersih meningkat menjadi Rp 44.230 atau 73,72\% karena biaya pakan bisa ditekan.
\end{abstract}

Kata kunci: Mesin Penghalus, Dry Home, Pakan Bebek.

\begin{abstract}
The growth of the productive age population in Indonesia that is not matched by the availability of sufficient employment opportunities, causes an increase in unemployment. The government is promoting the entrepreneurship program as a solution to increasing unemployment. One entrepreneur that has good prospects is laying ducks. As a staple, demand for duck eggs on the market is relatively stable. This community partnership program aims to streamline the time to make shrimp head flour as the most important feed component in duck egg production. The process of making shrimp head flour made by Maros residents so far consists of 4 stages, namely: 1) Boiling shrimp heads, 2) Shrimp head drying, 3) Milling and 4) fineness. This community partnership program uses research and development methods. The results obtained from the implementation of this program are: 1) time efficiency from drying the shrimp head to making shrimp head flour from 2 days to 10 hours, 2) partners can operate the flour machine and utilizing technology, 3) shrimp flour production capacity increases due to shorter flour production time, 4) operating profit increased by Rp. 14,230 or 47.43\% and net cash flow increased to Rp. 44,230 or $73.72 \%$ due to reduced feed costs.
\end{abstract}

Keywords: Disk Mill, dry Home, Duck Farm,

\section{PENDAHULUAN}

Kemiskinan merupakan salah satu masalah serius yang dihadapi banyak negara. Oleh karena itu, berbagai usaha dikembangkan untuk menurunkan angka kemiskinan.
Kemiskinan sering kali dianalogikan dengan kondisi kehidupan di pedesaan. Padahal tingkat kemiskinan dapat dilihat pada cara masyarakat memenuhi kebutuhan hidupnya yang kian hari kian meningkat. Hal ini 
mengindikasikan bahwa kemiskinan tidak lagi merupakan masalah pada daerah pedesaan, tetapi juga sudah merambah ke daerah perkotaan. Dengan demikian perlu ditingkatkan produktivitas masyarakat secara mandiri dengan kata lain berwirausaha (Purwanti, 2012).

Pertumbuhan perekonomian yang lamban menyebabkan masih sedikitnya lapangan pekerjaan yang tersedia untuk masyarakat. Di samping itu, semakin meningkatnya pengangguran yang menyebabkan semakin tingginya tingkat kriminalitas dan angka kemiskinan sehingga hal ini menjadi sorotan pertama bagi pemerintah untuk mengatasi masalah tersebut. Oleh karena itu perlu penyelesaian masalah dengan berwirausaha untuk dapat menciptakan lapangan pekerjaan untuk menghasilkan pendapatan serta meningkatkan kesejahteraan masyarakat (Putra dkk, 2018).

Negara yang maju adalah negara yang memiliki wirausaha di atas $14 \%$ sehingga sektor-sektor perekonomian pada negara itu dapat bergerak dengan cepat. Dengan kata lain negara maju adalah negara yang memiliki masyarakat produktif. Indonesia sebagai salah satu negara berkembang masih memiliki jumlah wirausaha sebesar $3,1 \%$ oleh sebab itu perlu ditanamkan nilai-nilai wirausaha sejak dini (Kuwado, 2018).

Bebek termasuk salah satu jenis unggas yang diminati untuk dibudidayakan sebagai penghasil telur maupun daging (Winarso \& Ruvendi, 2018). Bebek dapat dibudidayakan dengan dua metode yaitu metode tradisional ataupun metode modern. Metode tradisional adalah metode dengan cara menggembalakan bebek di area persawahan. Metode ini tidak dapat diterapkan lagi karena dapat merusak tanaman padi di area persawahan sehingga petani dapat mengalami gagal panen.

Metode modern adalah metode beternak dengan menggunakan kandang dan pengaturan pemberian pakan. Pakan memiliki peranan yang sangat signifikan dalam produktivitas bebek petelur. Pembelian pakan adalah biaya operasional terbesar dalam proses produksi telur bebek (Tugiyanti dkk,2019).

Berangkat dari hal tersebut, peternak harus mengupayakan pembuatan pakan secara mandiri dengan menggunakan alat-alat dan metode tradisional yang dapat menekan biaya produksi. Pembuatan tepung kepala udang akan secara mandiri dengan metode tradisional sangat bergantung pada faktor cuaca (Pamungkas, 2017).

Udang di Indonesia termaksud salah satu komoditi ekspor ke berbagai negara tetangga. Udang di ekspor dalam bentuk beku yaitu udang yang telah mengalami cold storage setelah mengalami pemisahan kepala dan kulit. Sehingga kepala dan kulit udang ini menjadi limbah yang dapat menimbulkan masalah pencemaran lingkungan. Kepala udang dapat dimanfaatkan sebagai bahan baku pakan ternak sebagai salah satu solusi untuk mengurangi pencemaran lingkungan (Dompeipen dkk, 2016).

Peternak Bebek di Maros menggunakan keong sawah atau kelapa udang, limbah pertanian (dedak) sebagai bahan baku untuk pembuatan pakan. Pengusaha bebek petelur telah melakukan produksi pakan secara mandiri yaitu dengan tahapan perebusan kepala udang, penjemuran kepala udang, penggilasan dan penumbukan (penghancuran) kepala udang (latif dkk, 2017) (Pasaribu, 2007).

Berdasarkan beberapa rumusan masalah di atas maka tujuan yang akan dicapai pada pengabdian ini adalah memberikan pemahaman kepada masyarakat (mitra) untuk menggunakan mesin Disk Mill sebagai mesin penghalus kepala udang, selain itu memberikan pemahaman kepada masyarakat untuk menggunakan sistem Dry Home sehingga masyarakat tetap dapat menjalankan proses produksi pakan di saat cuaca tidak begitu terik atau musim hujan.

\section{BAHAN DAN METODE}

Pelaksanaan pengabdian dilakukan pada bulan JuniSeptember 2019 di Dusun Cambajawa, Desa Baruga, Kecamatan Bantimurung, Kabupaten Maros dengan jarak kampus ke lokasi sekitar $30 \mathrm{~km}$. Kegiatan ini merupakan perwujudan pelaksanaan tri dharma perguruan tinggi khususnya pada program PKM (Pengabdian kepada Masyarakat). Metode pelaksanaan kegiatan ini adalah metode pengembangan Research and Devlompent (Sugiyono, 2016) memiliki beberapa tahapan yaitu:

a. Identifikasi masalah

Identifikasi masalah dilakukan dengan cara observasi dan diskusi bersama mitra tentang proses produksi telur bebek yang selama ini dijalani oleh mitra.

b. Perancangan

Permasalahan mitra yang telah ditemukan pada tahap observasi di diskusikan bersama tim pelaksana dan merancang solusi yang akan ditawarkan kepada mitra. Desain pada tahap ini masih berbentuk draft (gambar).

c. Pabrikasi

Tahap pabrikasi adalah tahap untuk merealisasikan hasil perancangan yang telah dibuat sebelumnya. Proses pengelasan pemasangan rangka.

d. Pengujian

pengujian adalah tahap uji coba alat yang telah dikembangkan serta mengevaluasi hasil dari alat yang telah dikembangkan.

e. Pengaplikasian

Pengaplikasian adalah tahap akhir dari pelaksanaan kegiatan pengabdian ini, pada tahap ini alat yang telah dikembangkan diaplikasikan di lokasi mitra serta 
melakukan pelatihan singkat kepada mitra sehingga mitra dapat menggunakan alat secara mandiri.

\section{HASIL DAN PEMBAHASAN}

Hasil yang telah dicapai pada program kemitraan masyarakat (PKM) yang dilaksanakan di Dusun Cambajawa, Desa Baruga, Kecamatan Bantimurung, Kabupaten Maros adalah sebagai berikut:

1) Observasi (identifikasi masalah) dengan cara diskusi bersama mitra untuk mengetahui permasalahan yang dihadapi mitra dalam pengolahan pakan bebek petelur.

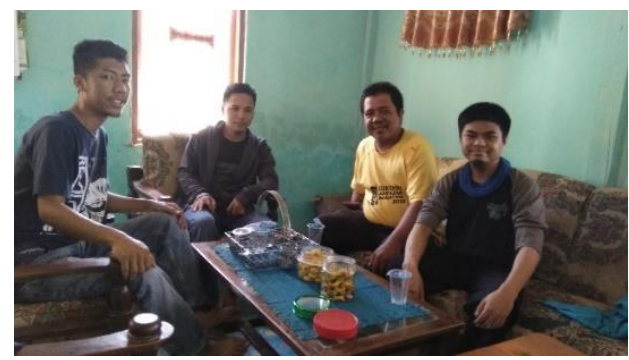

Gambar 1. Diskusi bersama mitra.

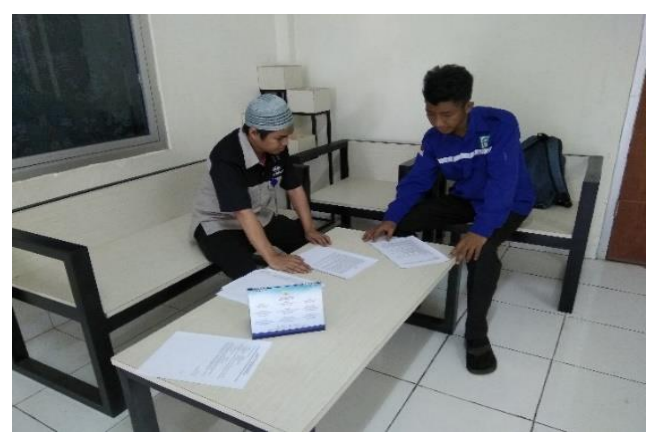

Gambar 2. Penandatanganan kontrak bersama mitra.

Hasil dari diskusi bersama mitra dan survei ke lokasi mitra maka ditemukan permasalahan yang di tengah dihadapi oleh mitra pada proses pembuatan pakan secara mandiri. Proses pembuatan pakan secara mandiri yang dilakukan oleh mitra selama ini terdiri dari beberapa tahap yaitu:

1. Proses perebusan kepala udang

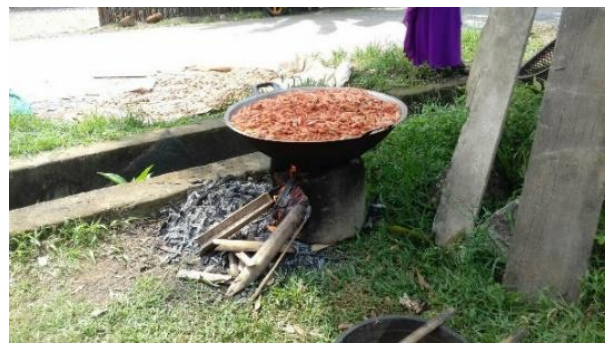

Proses ini dilakukan mitra untuk mengurangi kadar air pada kepala udang selain itu untuk mengurangi bau tidak sedap yang ditimbulkan kepala udang pada saat proses penjemuran.

2. Proses penjemuran kepala udang

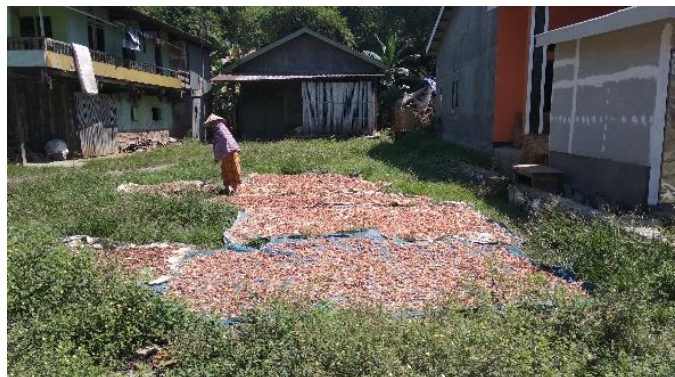

Proses penjemuran ini bertujuan untuk memudahkan penumbukan kepala udang untuk dibuat tepung. Proses ini penjemuran ini berlangsung \pm 8 jam pada saat matahari sedang terik sehingga proses ini sangat bergantung pada kondisi cuaca.

3. Proses penumbukan kepala udang

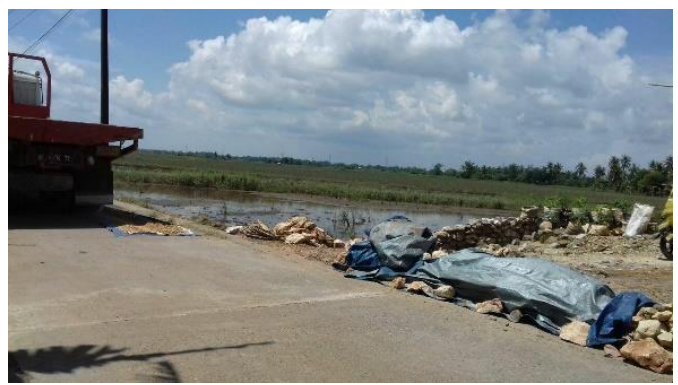

Proses penumbukan ini memanfaatkan mobil truk yang melintasi daerah mitra, sehingga mitra menjemur di jalanjalan setapak dengan harapan mobil yang melintas akan melindas kepala undang mitra.

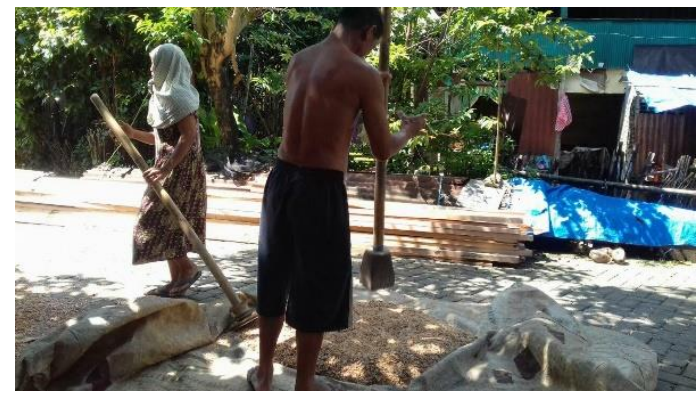

Proses selanjutnya adalah dengan menumbuk kepala udang yang telah dilindas oleh mobil truk. Proses ini untuk memaksimalkan penumbukan kepala udang.

2) Desain dan pabrikasi mesin penghancur, pembuatan rangka dudukan mesin Disk Mill dan Motor Penggerak. 


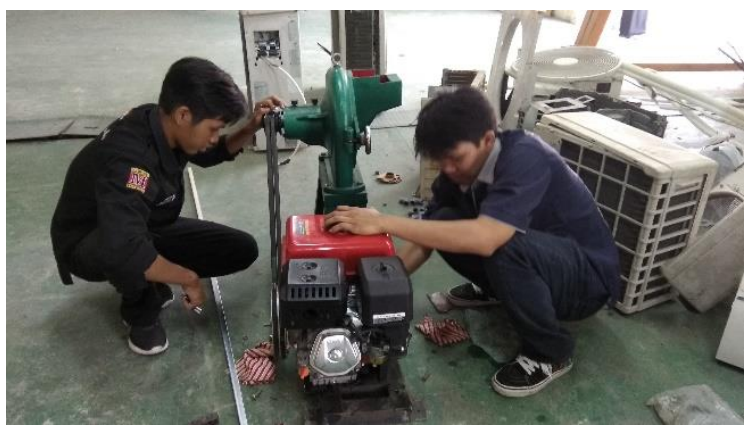

Gambar 3. Pemasangan Disk Mill dan Motor Penggerak.

Sosialisasi penggunaan Mesin penghalus kepala udang di lokasi mitra

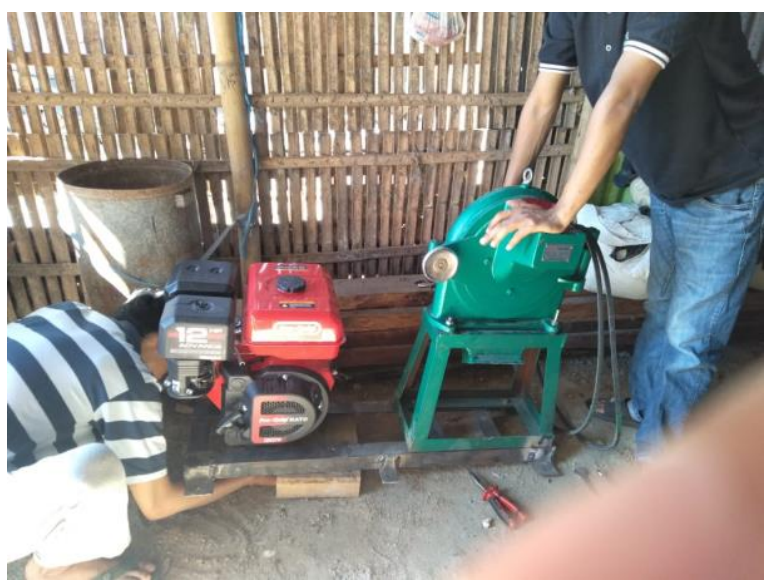

Gambar 4. Pemasangan Disk Mill dan motor Penggerak.

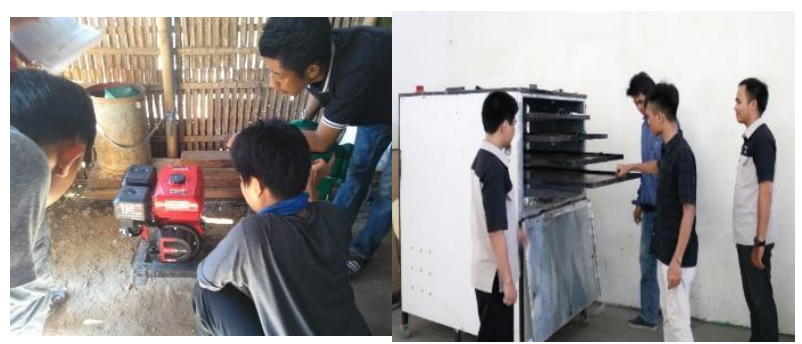

Gambar 5. Sosialisasi penggunaan mesin dan sistem Dry Home.

Proses sosialisasi dilakukan untuk memberikan pemahaman kepada mitra untuk menggunakan mesin penghalus kepala udang sehingga mitra dapat menggunakan mesin secara mandiri. Selain itu dilakukan kegiatan pendampingan untuk menentukan keberlanjutan dari program PKM ini. Kegiatan pendampingan diharapkan untuk menjaga keberlanjutan produksi tepung kepala udang sebagai bahan pakan ternak bebek petelur.
3) Keberhasilan kegiatan

Keberhasilan kegiatan dari program ini dapat dilihat dari pencapaian indikator keberhasilan yang telah ditentukan sebelumnya. Pengadaan mesin penghalus kepala udang serta pelatihan proses penggunaannya telah selesai dilaksanakan. Mesin telah dapat dioperasikan oleh mitra tanpa kendala.
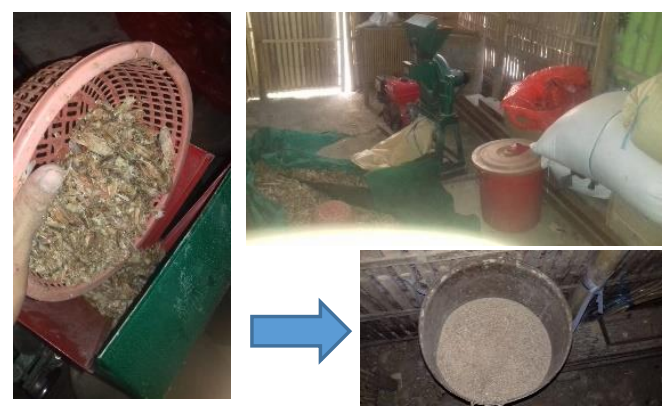

Gambar 6. Mitra mampu menggunakan mesin secara mandiri.

Perhitungan keuntungan didasarkan pada hasil penjualan rata-rata telur bebek setiap harinya dikurangi dengan biaya pakan per hari. Rata-rata $80 \%$ bebek bertelur setiap harinya. Harga jual telur bebek Rp. 2.500/butir. Komposisi pakan yang digunakan mitra selama ini dalam pembuatan pakan terdiri dari $2 \mathrm{Kg}$ dedak, $1 / 2 \mathrm{~kg}$ konsentrat, $2 \mathrm{~kg}$ tepung kepala udang. Biaya pakan dengan tepung kepala udang yang dibuat sendiri secara tradisional tidak bisa diukur karena waktu yang diperlukan untuk membuat tepung kepala udang tidak bisa dipastikan, tergantung pada cuaca. Komposisi pakan yang digunakan untuk 30 ekor bebek/hari dengan komponen tepung kepala udang yang dibeli adalah sebagai berikut:

Tabel 1. Biaya produksi pakan secara tradisional.

\begin{tabular}{|c|c|c|c|c|}
\hline No & Bahan & $\begin{array}{c}\text { Harga } \\
(/ \mathbf{k g})\end{array}$ & Qty & $\begin{array}{l}\text { Total } \\
\text { (Rp.) }\end{array}$ \\
\hline 1 & $\begin{array}{l}\text { Dedak } \\
\text { (ampas padi) }\end{array}$ & 3.500 & 2 & 7.000 \\
\hline 2 & Konsentrat & 10.000 & $1 / 2$ & 5.000 \\
\hline 3 & $\begin{array}{l}\text { Tepung } \\
\text { Kepala udang }\end{array}$ & 9.000 & 2 & 18.000 \\
\hline
\end{tabular}

Total Biaya 30.000

Untuk mengetahui bahwa investasi yang dilakukan bernilai positif atau mendatangkan keuntungan, maka terlebih dahulu dilakukan perhitungan selisih antara biaya investasi dengan aliran kas yang akan diperoleh. 
Perhitungan matematisnya adalah sebagai berikut :

Penjualan telur $/$ hari $=80 \% \times 30=24$ butir $/$ hari

Aliran kas/hari $=24$ x Rp. $2.500=$ Rp. 60.000/hari Aliran kas/hari - biaya pakan/hari $=$ Rp. $60.000-$ Rp. $30.000=$ Rp. $30.000,-$

Dari hasil perhitungan, diketahui bahwa dengan membeli tepung kepala udang, akan mendatangkan aliran kas bersih Rp. 30.000/hari.

Biaya pakan setelah menggunakan mesin penghalus kepala udang, mempunyai 2 komponen yaitu biaya tetap dan biaya variabel. Biaya tetap berupa biaya pembuatan mesin sedangkan biaya variabel adalah biaya pembelian kepala udang basah dan biaya bahan bakar untuk menjalankan mesin tersebut. Berdasarkan tabel kebutuhan pakan per hari di atas, maka selisih harga tepung udang yang dibeli dengan harga tepung udang yang dibuat sendiri, dapat dihitung sebagai berikut :

Biaya tetap pembuatan mesin $=\mathrm{Rp} 36.540 .000$

Setiap $25 \mathrm{~kg}$ kepala udang basah, bisa menghasilkan $7 \mathrm{~kg}$ tepung kepala udang dengan harga Rp 400/kg sehingga untuk mendapatkan $2 \mathrm{~kg}$ tepung kepala udang, perhitungannya adalah sebagai berikut :

Tepung kepala udang $=\frac{2}{7} \times 25 \times R p 400=\mathrm{Rp} 2.850$

Bahan bakar yang digunakan dalam membuat tepung kepala udang menggunakan mesin penghalus adalah bensin. Konsumsi bensin untuk menghasilkan $7 \mathrm{~kg}$ tepung kepala udang adalah 0,5 liter atau Rp 3.225. Dari data tersebut selanjutnya dapat dihitung konsumsi bensin untuk menghasilkan $2 \mathrm{~kg}$ tepung kepala udang yaitu :

Biaya bahan bakar $=\frac{2}{7} x \operatorname{Rp} 3.225=\operatorname{Rp} 920$

Total biaya pakan dengan tepung kepala udang yang dibuat sendiri, terlihat pada tabel berikut :

Tabel 2 Biaya Produksi menggunakan Disk Mill.

\begin{tabular}{clcr}
\hline No & \multicolumn{1}{c}{ Bahan } & Qty & $\begin{array}{c}\text { Total } \\
\text { (Rp.) }\end{array}$ \\
\hline 1 & $\begin{array}{l}\text { Dedak } \\
\text { (ampas padi) }\end{array}$ & 2 & 7.000 \\
2 & Konsentrat & $1 / 2$ & 5.000 \\
3 & Tepung & 2 & 2.850 \\
& Kepala udang & & 920 \\
4 & $\begin{array}{l}\text { Bahan bakar } \\
\text { Total Biaya }\end{array}$ & 15.770 \\
\hline
\end{tabular}

Dari data hasil penelitian di atas, maka aliran kas bersih yang bisa diperoleh per hari setelah menggunakan mesin Dry Home dan mesin tepung, dapat dihitung sebagai berikut :

Penjualan/hari - Biaya pakan/hari $=\mathrm{Rp} 60.000-\mathrm{Rp}$ $15.770=$ Rp 44.230

Penghematan biaya pakan $=\operatorname{Rp} 30.000-\operatorname{Rp} 15.770=R p$ 14.230
Peternak bebek dapat menghemat biaya pakan sebesar Rp 14.230/hari atau sebesar $47,43 \%$ jika menggunakan mesin Dry Home dan mesin tepung.

Kenaikan aliran kas bersih dari Rp 30.000,- menjadi Rp 44.230,- atau dari 50\% menjadi 73,72\%.

Lebih lanjut, dapat dihitung Payback Period sebagai berikut :

$$
\frac{\text { Biaya investasi mesin }}{\text { Aliran kas bersih } / \text { hari }}=\frac{R p 36.540 .000}{R p 44.230}=826,14 \text { hari }
$$

dengan jumlah bebek 30 ekor payback Period akan semakin pendek jika jumlah bebek ditambah.

a) Capaian pelaksanaan kegiatan

1. Kegiatan PkM di Desa Cambajawa Kabupaten Maros telah meningkatkan pemahaman pengusaha peternak bebek petelur untuk menggunakan sistem Dry Home untuk menjemur (pengeringan) kepala udang yang akan digunakan sebagai bahan baku pembuatan pakan sehingga proses pengeringan tidak bergantung lagi pada kondisi cuaca.

2. Kegiatan PkM di Desa Cambajawa Kabupaten Maros telah meningkatkan pemahaman pengusaha peternak bebek petelur untuk menggunakan mesin Disk Mill sehingga proses penghalusan kepala udang menjadi lebih efisien.

b) Dampak pelaksanaan kegiatan

1. Peningkatan kapasitas produksi pakan menggunakan sistem Dry Home dan Disk Mill

2. Mengurangi biaya produksi pakan dapat dilihat pada tabel 2 .

\section{KESIMPULAN}

Melalui program PkM (Pengabdian kepada Masyarakat) peningkatan pemahaman pengusaha bebek petelur menggunakan sistem Dry Home dan mesin penghalus kepala udang pada Desa Cambajawa Kabupaten Maros tahun 2019 telah banyak memberikan pengetahuan bagi masyarakat peternak bebek petelur seperti:

1) Pengusaha bebek petelur telah mampu memanfaatkan sistem Dry Home untuk proses penjemuran kepala udang sehingga proses produksi tidak dipengaruhi oleh kondisi cuaca lagi.

2) Pengusaha bebek petelur dapat mengefisienkan waktu penghalusan kepala udangnya menggunakan mesin penghalus kepala udang (Disk Mill)

3) Pengusaha dapat menekan biaya produksi tepung kepala udang sebagai salah satu bahan untuk pakan bebek petelur

\section{UCAPAN TERIMA KASIH}

Penulis menyampaikan terima kasih kepada DRPM Kemenristekdikti, mitra "usaha bebek petelur Amir", warga Dusun Cambajawa Dusun Baruga Kec, Bantimurung Kab. Maros, LPPM Politeknik Bosowa, Mahasiswa Politeknik Bosowa Prodi Perawatan dan Perbaikan Mesin (PPM), Prodi Teknik Listrik (TLS) dan 
Prodi Perpajakan (PJK) serta pihak-pihak yang tidak penulis sebutkan satu persatu, berkat dukungan, bantuan, dan motivasinya sehingga PKM ini dapat terlaksana sebagaimana mestinya.

\section{DAFTAR PUSTAKA}

Dompeipen, E. J., Kaimudin, M., \& Dewa, R. P. (2016). Isolasi kitin dan kitosan dari limbah kulit udang. Majalah BIAM.

Kuwado, F. J. (2018). Jumlah Entrepreneur di Indonesia Jauh di Bawah Negara Maju, Ini Kata Jokowi.

latif, sukron, Suprijatna, E., \& Sunarti, D. (2017). Performans produksi telur puyuh yang diberi ransum tepung limbah udang fermantasi. Jurnal Ilmu-Ilmu Peternakan. https://doi.org/10.21776/ub.jiip.2017.027.03.06

Pamungkas, P. A. (2017). Potensi usaha ternak bebek petelur di kampung bebek desa kebonsari kecamatan candi kabupaten sidoarjo. Swara Bhumi.

Pasaribu, T. (2007). Produk fermentasi limbah pertanian sebagai bahan pakan unggas di Indonesia. Wartazoa.

Purwanti, E. (2012). Pengaruh Karakteristik Wirausaha, Modal Usaha, Strategi Pemasaran Terhadap Perkembangan Umkm Di Desa Dayaan Dan Kalilondo Salatiga. Among Makarti.

Putra, P. D., Efendi, H., Wuyung, W., Brata, W., Pendidikan, J., Niaga, T., ... Ternak, P. (2018). PENINGKATAN PENDAPATAN PETERNAK BEBEK MELALUI PELATIHAN PAKAN TERNAK DAN KEWIRAUSAHAAN. JURNAL PENGABDIAN DAN PEMBERDAYAAN $M A S Y A R A K A T$.

Sugiyono, P. D. metode penelitian kuantitatif, kualitatif,dan R\&D. , Alfabeta, cv. (2016).

Tugiyanti, E., Mugiyono, S., \& Harisulistyawan, I. (2019). Aplikasi Antioksidan Alami Daun Sukun Fermentasi terhadap Produktivitas Itik di KTTI "Unggas Jaya." Jurnal Surya Masyarakat. https://doi.org/10.26714/jsm.1.2.2019.132-138

Winarso, B., \& Ruvendi, R. (2018). SISTEM PEMASARAN HASIL TERNAK ITIK DI INDONESIA TINJAUAN KASUS DI PROPINSI JAWA TENGAH DAN JAWA TIMUR. Jurnal Ilmiah Binaniaga.

https://doi.org/10.33062/jib.v2i01.200 